\title{
المقابر الليكية
}

•د.عبير عبد المحسن قاسم

تزخر المقابر الليكية بالعديد من الأنواع، ويذكر المؤرخ "بلينى" أن منطقة ليكيا

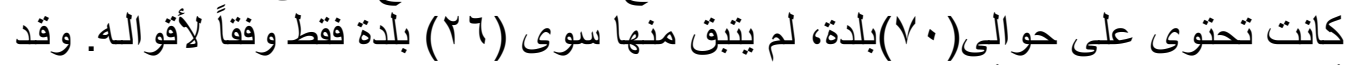

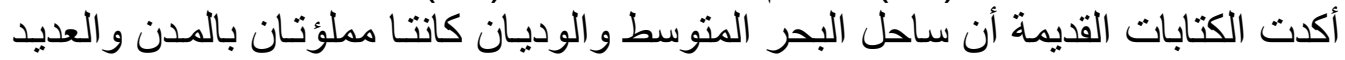

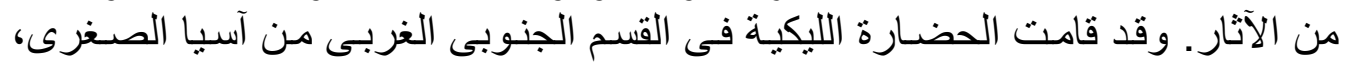

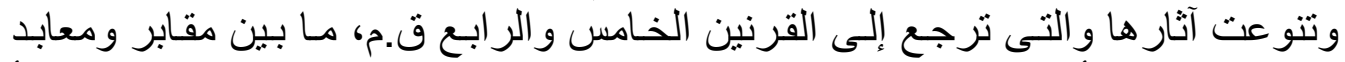

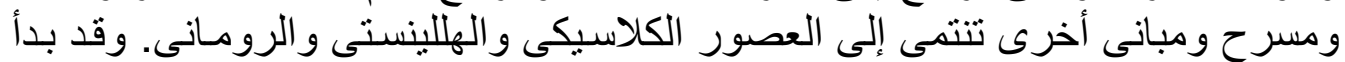

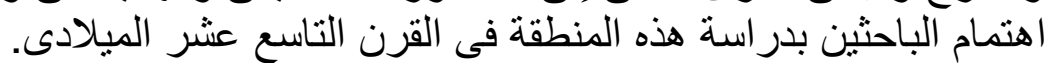

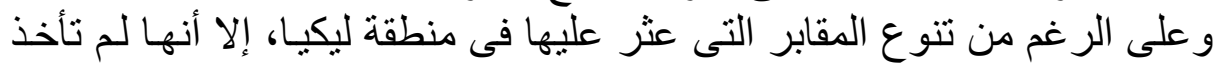

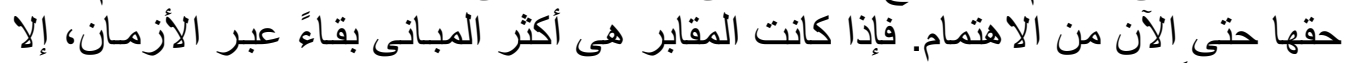

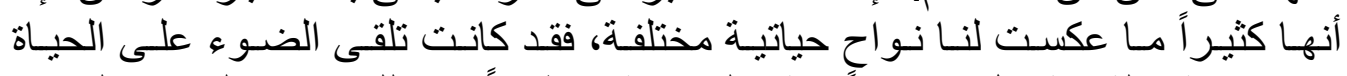

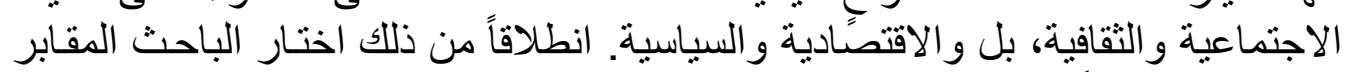

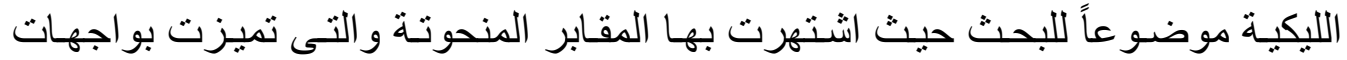
معمارية كان لها تأثثر و اضح على على المقابر فى المنـاطق الأخرى، وأهمها مقابر منطقة

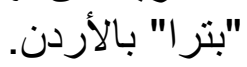

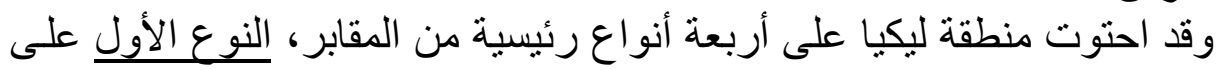

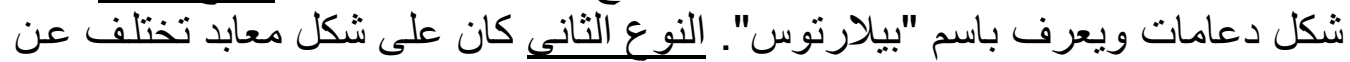

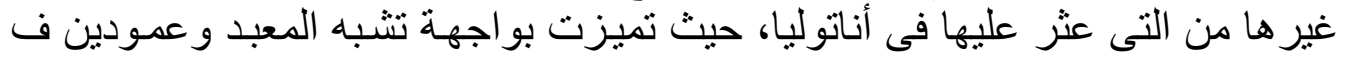

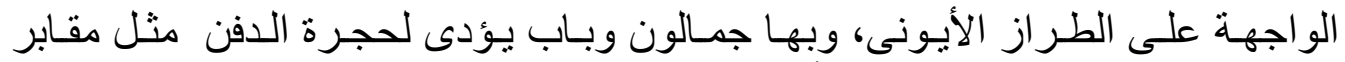

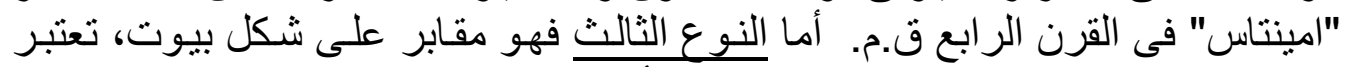

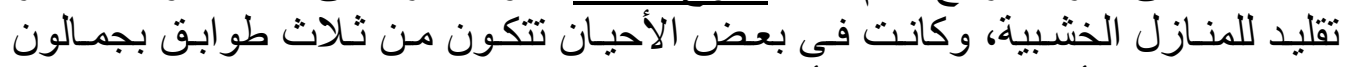

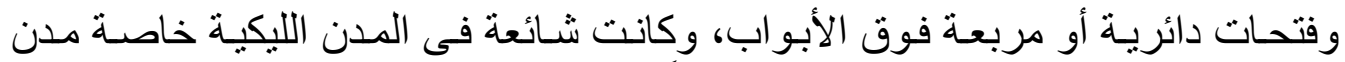

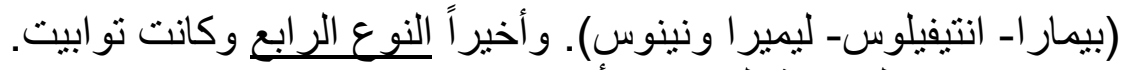

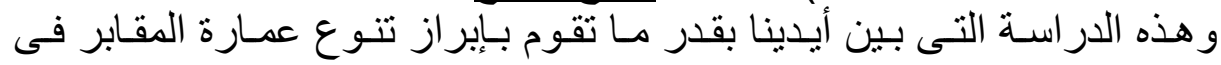

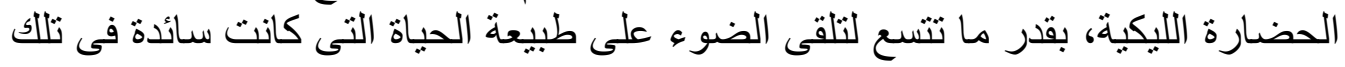
المناطق.

• أستاذ مساعد الاثار اليونانية الرومانية ـ كلية الآداب ـ جامعة دمنهور ـ ألقي ملخص البحث ولم

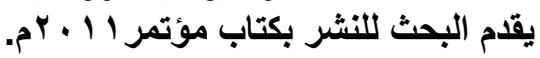

